\title{
Problematyka podatku od niezrealizowanych zysków kapitałowych w przypadku zmiany siedziby lub miejsca zamieszkania w świetle orzecznictwa Trybunału Sprawiedliwości Unii Europejskiej
}

\section{JEL Classification: K34}

Słowa kluczowe: exit tax, dyrektywa ATAD, unikanie opodatkowania

Keywords: exit tax, ATAD, tax avoidance

\begin{abstract}
Abstrakt: Wraz z początkiem bieżącego roku weszła w życie nowelizacja ustawy o podatku dochodowym od osób fizycznych, ustawy o podatku dochodowym od osób prawnych, ustawy Ordynacja podatkowa oraz niektórych innych ustaw, wprowadzająca nieznany wcześniej polskiemu prawu podatek od niezrealizowanych zysków, ta zwany podatek wyjścia (ang. exit tax). Problematyka tego podatku od momentu jego wprowadzenia do prawa unijnego w ubiegłym dziesięcioleciu pozostaje szeroko dyskutowana. Państwa członkowskie UE chętnie korzystają z tego sposobu dofinansowywania swoich budżetów, nierzadko implementując do swoich systemów exit tax w sposób, którego zgodność z traktatami może budzić wątpliwości. Szczególnie wyraźnie odznacza się na tym polu problem godzenia podatku wyjścia w wolności wspólnotowe, takie jak wolność przemieszczania się czy podejmowania działalności gospodarczej. Swobody te, będące fundamentami wspólnotowego dobrobytu i motorem napędowym unijnej gospodarki, są jednocześnie niezbędnym ogniwem w osiąganiu celów traktatu z Lizbony. W świetle powyższego należy podkreślić istotność odpowiedniej implementacji exit tax do systemów państw członkowskich. Wymaga ona od ustawodawców wysokiego poziomu precyzyjności czy wręcz ,wstrzemięźliwości" przy tworzeniu odpowiednich aktów prawnych. Polski ustawodawca zdaje się o tym zapominać, co potwierdza analiza nowelizacji ustawy o podatku dochodowym od osób fizycznych i prawnych. Ustawa wydaje się nie być dostatecznie dopracowana, nasuwają się pytania o tak podstawowe kwestie, jak ustalenie dnia zmiany rezydencji podatkowej czy zgodność z prawem traktatowym
\end{abstract}

* Opiekun naukowy (Scientific Tutor) — Łukasz Chyla 
„nadgorliwego" rozciągnięcia tegoż podatku na osoby fizyczne nieprowadzące działalności gospodarczej.

Niniejszy artykuł skupi się na wieloaspektowej analizie najbardziej problematycznych zagadnień związanych ze stosowaniem w praktyce uregulowań dotyczących nowego podatku oraz ogólnej ocenie uregulowań krajowych i unijnych w zakresie takiego opodatkowania. Uregulowania poszczególnych państw członkowskich Unii Europejskiej bywały bowiem częstym przedmiotem orzekania Trybunału Sprawiedliwości Unii Europejskiej, a ich zgodność z prawem pierwotnym Unii wielokrotnie kwestionowana i podważana. Wobec powyższego przy wprowadzaniu do porządków krajowych niniejszych przepisów wymagana jest od ustawodawcy szczególna ostrożność i zważenie na możliwość ewentualnego naruszenia swobód europejskich. Na koniec podane zostaną ewentualne postulaty de lege lata i de lege ferenda dla polskiego ustawodawcy oraz ogólna ocena zgodności polskich uregulowań z Traktatem o Unii Europejskiej oraz Traktatem o funkcjonowaniu Unii Europejskiej.

\title{
The issue of exit tax in the light of the Court of Justice of the European Union's judgements
}

\begin{abstract}
With the beginning of 2019 the amendment to Polish tax acts' has entered into force and it has introduced new tax that had never before been known in Polish law - exit tax. The issue of exit tax has been problematic for European countries' legislators ever since it was introduced back in the previous decade. It was enthusiastically received by them as it provides an extra source for the country's budget. However, the adoption of the tax to national law systems is highly complicated - the basis for such duty may stand in oppostion to most important European rules, such as the principle of free movement or the right of establishment. These freedoms, which underpin the internal market, are the driving force behind the economic prosperity in the EU and the prerequisite for achieving the aims of the Lisbon Strategy. Thus, it is crucial to implement regulations regarding the exit tax with scrutiny and high preciseness.

This article focuses on a multifaceted analysis of the most problematic issues regarding the application of the new tax and the overall assessment of Polish and European acts on tax. The Court of Justice of the European Union has often negatively reviewed the regulations of individual Member States. Regarding the abovementioned, some substantial actions have to be undertaken by the lawmakers in order to ensure the compatibility of national acts with basic EU aims.
\end{abstract}

\section{Wstęp}

W związku z wejściem w życie od 1 stycznia 2019 roku ustawy z dnia 23 października 2018 roku o zmianie ustawy o podatku dochodowym od osób fizycznych, ustawy o podatku dochodowym od osób prawnych, ustawy - Ordynacja podatkowa oraz niektórych innych ustaw polscy podatnicy będą zmuszeni zmierzyć się z nowymi trudnościami w rozliczeniach z fiskusem. Ustawa nowelizująca stanowi implementację do polskiego porządku prawnego Dyrektywy Rady (UE) 2016/1164 z 12 lipca 2016 roku - The Anti Tax Avoidance Directive (ATAD), której głównym celem jest zapobieganie unikania opodatkowania dzięki ujednoliceniu uregulowań podatkowych państw członkowskich. Istotą exit tax w rozumieniu dyrektywy jest opodatkowanie niezrealizowanych zysków kapitałowych w związku z przeniesieniem przez podatnika aktywów jego przedsiębiorstwa do 
innego kraju. Polski ustawodawca rozciągnął jednak jego stosowanie także na osoby fizyczne nieprowadzące działalności gospodarczej. Jest to swoista rekompensata dla państwa, które traci prawo do opodatkowania dochodu efektywnie wygenerowanego przed przeniesieniem. Ze względu na to, że przepisy obejmują dziedzinę, która dotychczas nie była uregulowany w polskim systemie podatkowym, zainteresowanie nimi było szczególne już od samego początku drogi ustawodawczej.

\section{Wytyczne OECD w sprawie zapobiegania erozji podstawy opodatkowania (BEPS) oraz dyrektywa ATAD}

Podatek od niezrealizowanych zysków, którego nakładanie przewiduje dyrektywa ATAD, jest chętnie wprowadzany przez wielu ustawodawców państw europejskich i stał się narzędziem do efektywnego powiększania państwowych budżetów. Zgodnie z unijnymi przepisami państwa otrzymały możliwość wprowadzenia przepisów skutkujących opodatkowaniem niezrealizowanych zysków kapitałowych już w chwili przeniesienia przez przedsiębiorstwo aktywów za granicę. Dyrektywy ATAD należą do większego ,pakietu” unijnych uregulowań adaptowanych w celu zapobiegania tak zwanej erozji podstawy opodatkowania (Base Erosion Profit Shifting — BEPS). Jest ona najbardziej rażącym efektem ubocznym międzynarodowych konwencji i umów, których celem była ochrona podatnika przed podwójnym opodatkowaniem, a które stały się niejako instrumentem umożliwiającym podwójne jego unikanie. Termin BEPS został rozpowszechniony po wydaniu w 2013 roku przez Organizację Współpracy Gospodarczej i Rozwoju (OECD) raportu ${ }^{1}$. Zobowiązuje on państwa do walki z planowaniem podatkowym wykorzystującym luki oraz rozbieżności w uregulowaniach podatkowych, mające na celu ukrywanie bądź transferowanie dochodu do miejsc o niskich stawkach podatkowych, w których podatnik nie wykazuje szczególnej aktywności gospodarczej $^{2}$. Zawiera on 15 zaleceń działań, jakie powinny być podejmowane przez państwa w celu zapobiegania nieuczciwemu unikaniu opodatkowania i przenoszeniu zysków do rajów podatkowych ${ }^{3}$. Zapewnienie minimum ochrony przed erozją podstawy opodatkowania jest więc także głównym celem dyrektywy ATAD.

Zgodnie z art. 5 ust. 1 dyrektywy opodatkowani mogą być przedsiębiorcy:

— przenoszący rezydencję podatkową do innego państwa członkowskiego lub państwa trzeciego, z wyjątkiem aktywów, które pozostają faktycznie powiązane ze stałym zakładem w pierwszym państwie członkowskim;

1 Raport OECD nt. przeciwdziałania BEPS znany również jako Plan Działań BEPS (Action Plan on Base Erosion and Profit Shifting), 19.07.2013, http://www.oecd.org/ctp/beps-2015-final-reports.html (dostęp: 22.02.2019).

2 http://www.oecd.org/ctp/beps-about.html (dostęp: 22.02.2019).

3 A. Wieśniak-Wiśniewska, M. Czerwiński, Świat podatków po projekcie BEPS i jego wptyw na polskich podatników, „Przegląd Podatkowy” 2016, nr 6, s. 22-31. 
— przenoszący prowadzoną przez swój stały zakład działalność gospodarczą z jednego państwa członkowskiego do innego państwa członkowskiego lub do państwa trzeciego;

— przenoszący aktywa ze swojej siedziby głównej do stałego zakładu w innym państwie członkowskim UE lub w państwie trzecim;

- przenoszący aktywa ze swojego stałego zakładu w państwie członkowskim do swojej siedziby głównej lub innego stałego zakładu w innym państwie członkowskim lub w państwie trzecim.

\section{Ustawa z dnia 23 października 2018 roku o zmianie ustawy o podatku dochodowym od osób fizycznych, ustawy o podatku dochodowym od osób prawnych, ustawy - Ordynacja podatkowa oraz niektórych innych ustaw. Najważniejsze zmiany}

W Polsce dyrektywa ATAD została implementowana w postaci nowelizacji ustaw o podatku dochodowym od osób fizycznych oraz prawnych i niektórych innych ustaw. Oprócz opodatkowania niezrealizowanych zysków kapitałowych w związku z przeniesieniem przez podatnika aktywów jego przedsiębiorstwa polski ustawodawca zdecydował się objąć tym podatkiem także polskich rezydentów podatkowych nieprowadzących działalności gospodarczej, którzy zmieniają rezydencję podatkową bądź przenoszą składnik majątku poza terytorium Rzeczypospolitej Polskiej. Zarówno w jednym, jak i drugim wypadku nie dochodzi do przeniesienia własności, jednak czynności te skutkują pozbawieniem państwa prawa do opodatkowania dochodu efektywnie wygenerowanego na jego terytorium.

W wypadku składnika majątku niezwiązanego z działalnością gospodarczą opodatkowanie exit tax $\mathrm{w}$ razie zmiany rezydencji podatkowej obejmie podatnika, który przed zmianą rezydencji mieszkał w Polsce przez co najmniej pięć lat w okresie dziesięciu lat poprzedzających „,wyprowadzkę”. Należy pokreślić, że podatek obejmie jedynie udziały w spółkach, akcje i inne papiery wartościowe, pochodne instrumenty finansowe czy tytuły uczestnictwa w funduszach kapitałowych, nie będzie natomiast należny od oszczędności czy nieruchomości. Zobowiązanie podatkowe zaktualizuje się, gdy łączna wartość przenoszonego majątku osoby fizycznej przekroczy 4 miliony złotych do 7 dnia miesiąca następującego po miesiącu dokonania decydującego przeniesienia podatnik jest zobowiązany do złożenia deklaracji i wpłacenia należnego podatku.

Exit tax występuje w dwóch stawkach — 3\%, która będzie miała zastosowanie tylko w wypadku przenoszenia składników majątku, których wartości podatkowej się nie ustala (o zryczałtowanej formie opodatkowania), oraz 19\%, gdy ustalana jest wartość podatkowa składnika majątku. Ta ostatnia obejmie najprawdopodobniej większość przypadków. 
Zgodnie z art. 30 da ust. 7 ,dochód z niezrealizowanych zysków stanowi nadwyżka wartości rynkowej składnika majątku ustalanej na dzień jego przeniesienia albo na dzień poprzedzający dzień zmiany rezydencji podatkowej ponad jego wartość podatkową". W tym miejscu pojawia się pierwszy problem, jakim jest ustalenie dnia zmiany rezydencji podatkowej, który nie musi przecież pokrywać się z dniem wyjazdu z kraju — należy tu brać pod uwagę miejsce zamieszkania rodziny czy ośrodek interesów życiowych i gospodarczych.

Artykuły $30 \mathrm{db}$ i dc ustawy o podatku dochodowym od osób fizycznych przewidują wyłączenie opodatkowania dotyczącego minimalnej wartości przenoszonych składników (4 miliony złotych, także w przypadku małżonków) oraz — przy spełnieniu dodatkowych warunków — krótkotrwałe przeniesienie (maksymalnie na okres 12 miesięcy).

Kolejny artykuł ustawy przewiduje możliwość odroczenia i rozłożenia na raty wpłaty podatku. Jego wprowadzenie było konieczne ze względu na wcześniejsze orzecznictwo Trybunału Sprawiedliwości Unii Europejskiej. Pod koniec 2015 roku z pytaniem prejudycjalnym dotyczącym sposobu stosowania exit tax zgłosiła się do Trybunału brytyjska izba podatkowa. Podniosła w nim problem zgodności takiej daniny z zasadą swobody gospodarczości, szczególnie przy założeniu braku możliwości odroczenia jej zapłaty tudzież rozłożenia na raty. Taką możliwość TSUE jednoznacznie odrzucił, wskazując jej niezgodność z prawem pierwotnym UE.

\section{Ocena uregulowań ustawy nowelizującej w świetle jej adekwatności i proporcjonalności do celów dyrektywy ATAD na podstawie opinii podmiotów konsultowanych w trakcie procedury legislacyjnej}

Na początku należy zwrócić uwagę na dyskusyjność adekwatności daty wejścia w życie nowych przepisów - mimo że dyrektywa ATAD zobowiązuje państwa do zapewnienia jej skuteczności dopiero od 2020 roku, polski ustawodawca zdecydował się na nowelizację prawa podatkowego ze skutkiem już od 1 stycznia 2019 roku. Efektem tych pospiesznych działań był brak należytych konsultacji eksperckich czy społecznych, które pozwoliłyby na dostosowanie uregulowań do potrzeb samych zainteresowanych. Wobec licznych wątpliwości pojawiających się zarówno u podatników, jak i fiskusa Ministerstwo Finansów opublikowało na początku bieżącego roku projekty rozporządzeń wykonawczych do ustaw o PIT i CIT, zawierające informację o sposobach stosowania tego podatku oraz wzory nowych deklaracji podatkowych. Niedługo po tym wydane zostało rozporządzenie w sprawie przedłużenia terminu wpłacania podatku od niezrealizowanych do 7 lipca bieżącego roku. Takie działania nie mogą jednak być uznane za wystarczające do zapewnienia prawidłowego funkcjonowania ustawy. Na pierwszy plan przy jej analizie wysuwa się potencjalny nadmiar uregulowań w tym przedmiocie. W październiku 2018 roku Instytut Staszica wydał analizę (obecnie funkcjonują- 
cego już jako ustawa) projektu, w której uznaje, że jest ona „rażącym przykładem zjawiska nadregulacji”4. Trudno się zgodzić z takim stanowiskiem w odniesieniu do całości nowych uregulowań, zdecydowanie jest ono jednak adekwatne w kwestii opodatkowania exit tax osób fizycznych. Takie rozszerzenie zakresu podmiotowego nowej daniny wykracza wyraźnie poza minimum konieczne do osiągnięcia celów wyrażonych w dyrektywie i stoi w sprzeczności z jej preambułą, która wskazuje, że „nie jest wskazane rozszerzenie zakresu działania niniejszej dyrektywy na podmioty niepodlegające podatkowi od osób prawnych w państwie członkowskim”, a także że jej cel „można osiągnąć poprzez ustanowienie minimalnego poziomu ochrony krajowych systemów podatku od osób prawnych"5. Na możliwą nadregulację w tym wypadku wskazywały podczas konsultowania projektu ustawy także takie organizacje, jak Konfederacja Lewiatan czy Krajowa Izba Radców Prawnych. Uwagi te nie zostały jednak uwzględnione przez parlament i kształt obecnej ustawy nie odbiega w tym przedmiocie od jej projektu.

Innym istotnym mankamentem ustawy jest nakaz złożenia deklaracji i zapłaty podatku w ciągu 7 dni od dnia zmiany rezydencji podatkowej na podstawie wyceny aktywów. Dla zainteresowanych podmiotów będzie to skutkowało opodatkowaniem wartości niemierzalnej i niewymiernej, potencjalnego zysku, nawet jeśli finalnie dane aktywa wygenerują stratę ${ }^{6}$. Takie zjawisko może finalnie zachwiać płynnością finansową przedsiębiorcy, a w skrajnych wypadkach prowadzić do upadłości. Remedium ma stanowić wspomniane odroczenie terminu płatności czy rozłożenie kwoty podatku na raty.

\section{Exit tax a swobody traktatowe - orzecznictwo Trybunału Sprawiedliwości Unii Europejskiej}

Do rozważenia zgodności w prawem unijnym uregulowań w sferze exit tax konieczne jest przypomnienie charakteru Unii i swobód przewidzianych traktatami, będących podstawą jej funkcjonowania. Traktaty założycielskie powołały bowiem do życia nowy, niespotykany wcześniej typ organizacji międzynarodo-

${ }^{4}$ Exit tax - między unijnymi wymogami a szkodliwą nadregulacją, analiza Instytutu Staszica dotycząca projektu ustawy o zmianie ustawy o podatku dochodowym od osób fizycznych, ustawy o podatku dochodowym od osób prawnych, ustawy - Ordynacja podatkowa oraz o zmianie niektórych innych ustaw, Warszawa, 24 października 2018 roku.

5 Dyrektywa Rady (UE) 2016/1164 z dnia 12 lipca 2016 roku ustanawiająca przepisy mające na celu przeciwdziałanie praktykom unikania opodatkowania, które mają bezpośredni wpływ na funkcjonowanie rynku wewnętrznego, https://eur-lex.europa.eu/legal-content/PL/TXT/PDF/?uri= CELEX:32016L1164\&from=PL (dostęp: 22.02.2019).

${ }^{6}$ Opinia Ośrodka Badań, Studiów i Legislacji Krajowej Rady Radców Prawnych do projektu z dnia 24 sierpnia 2018 roku ustawy o zmianie ustawy o podatku dochodowym od osób fizycznych, ustawy o podatku dochodowym od osób prawnych oraz ustawy - Ordynacja podatkowa, https:// legislacja.rcl.gov.pl/docs//2/12315309/12530095/12530098/dokument358223.pdf(dostęp: 22.02.2019). 
wej, a wraz z nią odrębny system prawny. W państwach członkowskich zaczęły równolegle obowiązywać dwa autonomiczne, niezależne systemy prawne, co powodowało niejednokrotnie problemy w określeniu pierwszeństwa stosowania. W ciągu lat Trybunał Sprawiedliwości UE wywiódł i ukształtował pewne niepisane zasady ogólne, między innymi zasadę supremacji prawa Unii Europejskiej oraz wywodzoną z niej zasadę pełnej skuteczności ${ }^{7}$. Zgodnie z nimi każde państwo członkowskie zobowiązane jest do zapewnienia prawu unijnemu pierwszeństwa w razie niezgodności z przepisami krajowymi, nawet tymi najwyższej rangi, a w razie sprzeczności — zapewnienia bezpośredniego stosowania prawa UE z pominięciem swoich przepisów wewnętrznych. Zasady te były podkreślane w najważniejszych orzeczeniach Trybunału, takich jak wydane w sprawach Internationale Handelsgesellschaft (C-11/70), Simmenthal (C-106/77) czy Flaminio Costa przeciwko Enel (C-6/64). Zasadę supremacji prawa unijnego nad prawem wewnętrznym RP znajdujemy ponadto w orzecznictwie Trybunału Konstytucyjnego. Przedmiotem jego orzekania była na początku ubiegłego dziesięciolecia możliwość przystąpienia RP do UE, ze szczególnym uwzględnieniem zgodności z Konstytucją obowiązującego brzmienia traktatu ateńskiego. W orzeczeniach K 18/04 (dotyczącym traktatu ateńskiego) oraz K 32/09 (dotyczącym traktatu z Lizbony) ${ }^{8}$ Trybunał wskazał, że prawo wewnętrzne powinno być zgodne z prawem wspólnotowym. W razie stwierdzenia przez sąd niezgodności przepisu z prawem unijnym ma on obowiązek pominięcia go przy wyrokowaniu, natomiast ustawodawca powinien podjać niezbędne kroki mające na celu wycofanie nieprawidłowych zapisów z porządku prawnego, a w ostateczności rozważyć nawet zmianę konstytucji lub wystąpienie z Unii.

Wobec faktu wysokiej dyskusyjności zgodności kształtu exit tax w poszczególnych państwach członkowskich z traktatami należałoby przeanalizować zapisy nowej polskiej ustawy i zastanowić się, czy rzeczywiście spełniają one standardy zachowania europejskich swobód.

Najistotniejsze wątpliwości w kwestii stosowania dyrektywy i przepisów ją implementujących budzi przestrzeganie podstawowych zasad prawa Unii Europejskiej: swobody przepływu kapitału, swobody przepływu towarów, swobody świadczenia usług, swobody przepływu osób oraz swobody przedsiębiorczości. Swobody rynku wewnętrznego wywodzą się prawa pierwotnego - znajdują się w części trzeciej TFUE zatytułowanej Polityki i działania wewnętrzne Unii, pod tytułem II (swobodny przepływ towarów — art. 28-37 TFUE) oraz tytułem IV (swoboda przepływu pracowników - art. 45-48 TFUE; swoboda przedsiębiorczości — art. 49-55 TFUE; swoboda świadczenia usług — art. 56-62 TFUE; swoboda przepływu kapitału i płatności — art. 63-66 TFUE).

7 J. Barcz, M. Górka, A. Wyrozumska, Instytucje i prawo Unii Europejskiej. Podręcznik dla kierunków prawa, zarządzania i administracji, Warszawa 2017, s. 302-304.

8 Ibidem, s. 460-469. 
Trybunał Sprawiedliwości Unii Europejskiej wielokrotnie wypowiadał się na temat exit tax, wskazując niezgodność jego konstrukcji z prawem wspólnotowym, właśnie ze względu na nadmierną ingerencję w swobody rynku wewnętrznego.

Pierwszy problem dotyczący exit tax sprowadza się do swobody przepływu osób i kapitału. Danina jest bowiem nakładana na osoby (fizyczne lub przedsiębiorstwa), które decydują się na wyemigrowanie, podczas gdy osoby niekorzystające ze swobody przemieszczania się nie są nim objęte. Takie opodatkowanie nie pozostaje bez wpływu na decyzję obywatela Unii odnośnie do przeprowadzki do innego kraju członkowskiego - zdecydowanie może do niej zniechęcać, a to już według utrwalonego orzecznictwa TSUE narusza podstawowe swobody obywatela Wspólnoty. Krajowi ustawodawcy bronią jednak stanowiska przeciwnego i tak zwanej międzynarodowej sprawiedliwości podatkowej ${ }^{9}$. Najważniejszy argument opiera się na fakcie zapewnienia przez państwo rezydencji środowiska do rozwoju emigrujących rezydentów, ulg czy zwolnień podatkowych, które w sposób pośredni przyczyniły się do rozwoju rezydenta i jego majątku. Taka logika nie może być pominięta, byłoby bowiem nie do przyjęcia osiąganie zysków z majątku zdobytego przez emigrującego w jednym kraju, który umożliwił mu jego osiągnięcie, przez nowe państwo rezydencji, które z rozwojem rezydenta nie miało wiele wspólnego. Krajowy interes podatkowy nie może być jednak przedkładany w hierarchii wartości nad zasadę swobody przepływu osób, kapitału i przedsiębiorczości, co zostało potwierdzone przez Trybunał Sprawiedliwości UE.

Jednym z pierwszych orzeczeń Trybunału na ten temat była sentencja z 2004 roku w sprawie Hughes de Lasteyrie de Saillant przeciwko Francji. W związku z tym, że de Saillant był znacznym udziałowcem we francuskiej spółce, po przeprowadzce do Belgii zapłacił podatek od niezrealizowanych zysków. Według Trybunału naruszyło to art. 52 TUE. W wyjaśnieniu czytamy, że mimo iż głównym celem artykułu 52 TUE było zapewnienie, że przedsiębiorcy będący rezydentami innych państw członkowskich będą traktowani w sposób niedyskryminujący i na równi z przedsiębiorcami z danego kraju, to jednak nie można zapomnieć o dalej idących konsekwencjach tegoż artykułu. Do takowych z pewnością należy zaliczyć nakaz dla państw członkowskich do powstrzymania się od działań, które nadmiernie utrudniałyby lub zniechęcały do podejmowania działalności gospodarczej przez swojego obywatela w innych państwach członkowskich.

Inne istotne orzeczenie w tej kwestii zapadło w sprawie Hiszpanii (C-64/11). Trybunał odrzucił co prawda zarzut niezgodności przepisów z dyrektywą, uznał jednak ich niezgodność z art. 49 TUE, to jest swobodą przedsiębiorczości. Szczególnie godził w nią zapis hiszpańskiej ustawy przewidujący natychmiastowy obowiązek zapłaty podatku przy przeniesieniu rezydencji podatkowej przedsiębiorstwa do innego kraju członkowskiego. Przy tej okazji Trybunał powołał

9 „Globalization and its socio-economic consequences”, 16th International Scientific Conference, 5th-6th October 2016, Rajecke Teplice, Slovak Republic, Proceedings Part III. 
się na swoje wcześniejsze orzeczenie o sygnaturze C-38/11 w sprawie Portugalii i przypomniał, że żadne uregulowania krajowe ani wspólnotowe prawo wtórne nie mogą zabraniać ani nadmiernie utrudniać swobody podejmowania działalności gospodarczej na terenie Wspólnoty.

\section{Podsumowanie}

Mimo głównego celu w postaci zapobiegania unikania opodatkowania, przerzucania dochodu z państwa do państwa i zabezpieczenia krajowego interesu fiskalnego dyrektywa ATAD może przy nieodpowiednim dookreśleniu przez państwa członkowskie doprowadzić do naruszenia podstawowych zasad i swobód obowiązujących w Unii Europejskiej. Jakkolwiek uregulowania wielu państw członkowskich Unii bywały nierzadko przedmiotem wyrokowania TSUE i niejednokrotnie uznawane za niezgodne z prawem traktatowym, zdaje się że polski ustawodawca nie wziął tego pod odpowiednią rozwagę przy nowelizowaniu ustaw podatkowych. Na pierwszy plan wysuwa się rozciągnięcie exit tax na osoby nieprowadzące działalności gospodarczej, mimo braku takiej konieczności wynikającego z dyrektywy. Takie rozszerzenie zakresu zastosowania podatku było możliwe dzięki specyficznej konstrukcji podatku projektowanej w dyrektywie oraz szerokiej swobodzie działania państw w zakresie dookreślenia sytuacji zastosowania omawianego podatku. Widoczny jest co prawda w ustawie nowelizującej wpływ orzecznictwa TSUE na kształt i zasady stosowania exit tax, między innymi w uregulowaniach dotyczących rozłożenia podatku na raty bądź odroczenia jego spłaty, jednak jak wskazuje niniejsza analiza, rozciągnięcie obowiązku podatkowego na osoby fizyczne jest co najmniej kontrowersyjne i w razie poddania pod wykładnię unijnemu trybunałowi stwierdzenie niezgodności takiego rozszerzenia z celami dyrektywy i traktatami założycielskimi będzie wysoce prawdopodobne.

\section{Bibliografia}

Barcz J., Górka M., Wyrozumska A., Instytucje i prawo Unii Europejskiej. Podręcznik dla kierunków prawa, zarządzania i administracji, Warszawa 2017.

Exit tax - między unijnymi wymogami a szkodliwa nadregulacja, analiza Instytutu Staszica dotycząca projektu ustawy zmianie ustawy o podatku dochodowym od osób fizycznych, ustawy o podatku dochodowym od osób prawnych, ustawy - Ordynacja podatkowa oraz o zmianie niektórych innych ustaw, Warszawa, 24 października 2018 roku.

„Globalization and its socio-economic consequences”, 16th International Scientific Conference- 5th - 6th October 2016 Rajecke Teplice, Slovak Republic, Proceedings Part III.

Opinia Ośrodka Badań, Studiów i Legislacji Krajowej Rady Radców Prawnych do projektu z dnia 24 sierpnia 2018 roku ustawy o zmianie ustawy o podatku dochodowym od osób fizycznych, ustawy o podatku dochodowym od osób prawnych oraz ustawy — Ordynacja podatkowa, https://legislacja.rcl.gov.pl/docs//2/12315309/12530095/12530098/dokument358223.pdf (dostęp: 22.02.2019).

Wieśniak-Wiśniewska A., Czerwiński M., Świat podatków po projekcie BEPS i jego wpływ na polskich podatników, „Przegląd Podatkowy” 2016, nr 6. 


\section{Akty prawne}

Dyrektywa Rady (UE) 2016/1164 z dnia 12 lipca 2016 roku ustanawiająca przepisy mające na celu przeciwdziałanie praktykom unikania opodatkowania, które mają bezpośredni wpływ na funkcjonowanie rynku wewnętrznego, https://eur-lex.europa.eu/legal-content/PL/TXT/PDF/?uri=C ELEX:32016L1164\&from=PL (dostęp: 22.02.2019).

Raport OECD nt. przeciwdziałania BEPS znany również jako Plan Działań BEPS (Action Plan on Base Erosion and Profit Shifting), 19.07.2013, http://www.oecd.org/ctp/beps-2015-final-reports. html (dostęp: 22.02.2019).

Ustawa z dnia 26 lipca 1991 roku o podatku dochodowym od osób fizycznych, http://isap.sejm.gov. pl/isap.nsf/download.xsp/WDU19910800350/U/D19910350Lj.pdf- (dostęp: 20.02.2019).

Ustawa z dnia 15 lutego 1992 roku o podatku dochodowym od osób prawnych, http://prawo.sejm. gov.pl/isap.nsf/download.xsp/WDU19920210086/U/D19920086Lj.pdf (dostęp: 20.02.2019).

Ustawa z dnia 23 października 2018 roku o zmianie ustawy o podatku dochodowym od osób fizycznych, ustawy o podatku dochodowym od osób prawnych, ustawy — Ordynacja podatkowa oraz niektórych innych ustaw, http://prawo.sejm.gov.pl/isap.nsf/download.xsp/ WDU20180002193/U/D20182193Lj.pdf (dostęp: 1.03.2019).

\section{The issue of exit tax in the light of the Court of Justice of the European Union's judgements}

\section{Summary}

Although the main aim of the Anti Tax Avoidance Directive (ATAD) is to prevent tax avoidance by transfering income from one country to another, inappropriate application of these rules may lead to a breach of the principles of the EU. Nevertheless, other countries' law has been often assesed by the Court of Justice of the European Union and has been proved to be contrary to the treaty law and it seems like the Polish legislator has not taken it into proper consideration when changing the law. The most vivid issue is covering with exit tax private individuals that do not carry out any commercial activities, despite the fact that such taxation is not necessary in the light of the ATAD. Such extension was possible due to the specific construct of the spoken tax and the wide margin of discretion of legislators adopting the regulations into national law systems. One can indeed notice that in the Polish act the Court of Justice of the European Union's judiciary has been taken it to consideration, especially when regulating the possibility of paying the tax in instalments or the postponement of the payment. Nevertheless, the extension of the tax onto private entities is at least controversial and probable to be considered inadequate by Court of Justice of the European Union. 